\title{
IMPACT OF UV-C STIMULATION OF TUBERS, IMMERSION OF POTATO STICKS IN WATER AND FRYING FAT TYPE ON THE CONTENT OF FAT IN DRY MASS OF FRENCH FRIES
}

\author{
Zygmunt Sobol $^{\mathrm{a}}$, Tomasz Jakubowski ${ }^{\mathrm{b}}$, Paulina Wrona ${ }^{\mathrm{c}}$ \\ a Faculty of Production and Power Engineering, University of Agriculture in Krakow, Poland \\ e-mail: Zygmunt.Sobol@urk.edu.pl ORCID 0000-0002-0082-7935 \\ b Faculty of Production and Power Engineering, University of Agriculture in Krakow, Poland \\ e-mail: Tomasz.Jakubowski@urk.edu.pl RCID 0000-0002-5141-2705 \\ c Faculty of Production and Power Engineering, University of Agriculture in Krakow, Poland \\ e-mail: paulina.wrona@urk.edu.pl ORCID 0000- 0001-8788-5566
}

*Corresponding author: e-mail: Zygmunt.Sobol@urk.edu.pl

\begin{tabular}{l}
\hline ARTICLE INFO \\
\hline Article history: \\
Received: January 2020 \\
Received in the revised form: \\
February 2020 \\
Accepted: March 2020 \\
\hline Key words: \\
UV-C stimulation, \\
potato tubers, \\
intermediates, \\
fat, \\
immersion in water \\
\hline
\end{tabular}

ABSTRACT
The aim of the experiment was to determine the impact of UV-C stim-
ulation of tubers, immersion of potato sticks in water, and a frying fat
type on the content of fat in dry mass of French fries. Tests were carried
out on Innovator tubers which is one of the most often used cultivator
in production of French fries by the European and Polish companies.
Radiation of potato tubers with ultraviolet in band C were performed
with the use of the original stand for stimulation of biological material
with electro-magnetic radiation. A statistical analysis of the obtained
results of tests indicates that stimulation of tubers and a type of frying
fat had a statistically significant impact on the fat content in dry mass
of French fries.

\section{Introduction}

Frying is one of the most popular thermal processes in preparation of food. The effect of this process: a superficial dehydration of the product, formation of smell compounds, change in colour and absorption of fat that occur in a short time. The process is very often used in obtaining food products mainly due to a short time of preparation as well as sensory values taste, smell, consistency. Products that are the most often obtained with this method are potato products, French fries, and crisps. The absorbed fat for fried potato products has a significant pro-health and sensory meaning. Due to health issues, a too high content of fat in products and its irrelevant quality is not recommended since it may lead to many metabolic diseases (Billek, 2000; Dobarganes et al., 2000; Saguy and Dana, 2003). Sensory aspects indicate, on the other hand, that a too high and too low-fat content is incorrect. The increased fat concentration in French fries and crisps causes that the products are rather not crisp but greasy. While, a too low-fat concentration causes that the external part or the whole product 
increases its hardness and there is a feeling of its rawness while eating. An organoleptic feeling is such as if a product was not fully fried (Lisińska, 1994; Lisińska, 2006; Pedreschi and Moyano, 2005).

Fat migration to a product while frying, according to many authors, takes place mainly with two mechanisms. The first one is related to a continuous absorption of fat resulting from replacement of water mass contained in an intermediate with fat where treatment takes place. It consists in formation of small channels in the cell structure of an intermediate as a result of sudden water vaporization, to which fat gets shortly after removal of water. The second mechanism takes place shortly after completion of a thermal treatment and consists in absorption of fat which is on the surface of the product to capillary spaces as a result of negative pressure during the stage of cooling (Lisińka, 1994; Aguilera and Gloria-Hernandez, 2000; Bouchon and Aguilera, 2001; Bouchon et al., 2001; Pedreshi et al., 2008). However, Dana and Saguy (2003) indicate that a condition of a raw material or intermediate is a significant parameter that decides on the total fat content in a product, namely the content of surfactants that absorb fat. Thus, the content of fat in French fries and crisps is affected by various factors that include properties of a raw material, the process of preparation of an intermediate, as well as the process of thermal treatment of products (Lisińska, 1994; Pedreschi et al., 2008; Krokida et al., 2000; Mellema, 2003; Zgórska and Smuga-Kogut, 2014). The most important are: the content of dry substance in raw material - density of raw material, often need to wash out reducing sugars from the surface of intermediate products through blanching, immersion of intermediate products in a water bath, washing out. The factors that influence the content of fat in fried products that result from the thermal processing are: a temperature and treatment time and a type of the used fat and its conditional quality that depends on the time of use. A shape of the intermediate product which influences the relation of the mass exchange (in the process of preparation for frying and frying) to the product volume (Zgórska and Smuga-Kogut, 2014; Friedman, 2000; Krokida et al., 2000; Moyano et al., 2006; RimacBrncic et al., 2004).

Physical methods are known based on the activity of electromagnetic wave whose activity causes a plant reaction. With reference to potato plants (Solanum tuberosum L.) an electromagnetic wave (Marks, 2005), microwave radiation (Jakubowski, 2015; Jakubowski, 2016) and irradiation with the ultraviolet light was applied (Jakubowski and Pytlowski, 2013). A reaction of the potato plant to a physical stimulus in the form of a variable magnetic field consisted in reduction of storage losses, the microwave radiation modified the germination process and short radiation of seed potatoes speeded up the germinations. In the aspect of storage processes and the yield quality in the period after its storage, the effect of ultraviolet operation in C band on limitation of infection of tubers with Rhizoctoniasolani Kühn may be significant (Jakubowski and Pytlowski, 2015).

The aim of the experiment was to analyse the impact of the UV-C stimulation of tubers, immersion of potato sticks in water and a frying fat type on the content of fat in dry mass of French fries. 
Impact of UV-C stimulation...

\section{Material and methods}

The experiment was carried out within 2017-2018. Potato tubers of Innovator cultivar were used as material for research. Innovator cultivar is one of the most eagerly used in production of French fries by the European companies as well as the Polish ones (Lisińska and Leszczyński, 1989). It is an early cultivar, culinary type B with tubers of a regular shape, round, and oval, of the average content of starch $14.6 \%$. This cultivar is very resistant to darkening of the pulp of raw material and after cooking it is suitable for storing. Intermediates for French fries were potato sticks with a cross- section of 10x10 mm and length of $60 \mathrm{~mm}$. Sticks were cut off along the longest axis of tubers, determined between the top and umbilical part. The process of immersion of intermediate products in water, related to extraction of reducing sugars was carried out in the investigated objects in the following combinations: (1) $-20^{\circ} \mathrm{C}$ within $15 \mathrm{~min}(2)-40^{\circ} \mathrm{C}$ within $20 \mathrm{~min}$. The tests include a combination with blanching of potato sticks (3) $-90^{\circ} \mathrm{C}$ and 2 min and control sample (0) - without immersion. The objects of tests after completion of immersion in water were dried immediately (in two stages) using each time a paper absorptive material (Sobol, 2006a; Sobol, 2006b; Sobol, 2007; Sobol, 2016). A stand for irradiation of a biological material with ultraviolet in $\mathrm{C}$ band had a form of a prismatic chamber with a cubic capacity of $0.63 \mathrm{~m}^{3}(0.55 \times 0.95 \times 1,2)$, the internal walls of which were made of aluminium (with a high coefficient of reflection). The chamber was equipped with a radiator type TUV UV-C NBV $15 \mathrm{~W}$ (intensity of irradiation of line $253.7 \mathrm{~nm}$ in the distance of $1 \mathrm{~m}$ from the lamp $=0.42 \mathrm{~W} \cdot \mathrm{m}^{-2}$, the total energy stream of a line $253.7 \mathrm{~nm}=4.0 \mathrm{~W}$ ). The radiator had a reflector made of a high-grade aluminium with a high coefficient of reflection (characteristics similar to a mirror). A structure of the radiator enabled smooth regulation of the height over the bottom of the chamber within 0.4 and 1.0 and was equipped with a precise time switch (model AURATON 100). Endurance of the UV-C radiator which means an invariability of parameters of its operation, was 8000 hours. Potato tubers during radiation were located on the flat, metal bottom with the surface area of $0.52 \mathrm{~m}^{2} .(0.55 \times 0.95)$. A precise characteristic of a test stand and methodology of UV$\mathrm{C}$ radiation is described in papers by Jakubowski and Wrona (2012) and Jakubowski and Pytlowski $(2013,2015)$. In order to irradiate potato tubers the following parameters of the UV-C simulation were applied: (1-3) - radiation 30 minutes on one side of the tuber (2) radiation 15 minutes from two opposite sides of the tuber, 0 - control sample (without radiation). Stimulation was carried out two days before formation of intermediates and their immersion in water. French fries were fried in two types of frying fat: (1) 0 coconut oil, (2) refined rapeseed oil. Temperature of frying was $170^{\circ} \mathrm{C}$ and frying time was 15 minutes. Fries were fried at one stage to the moment of achieving proper sensory parameters for the ready product. The relation of the mass of a batch (intermediate product) to the mass of frying fat was $1: 15$. The frying time was set in a separate initial experiment with an analysis of sensory reactions of a group of experienced persons who assessed them. Fried French fries were dried of excess of oil in two stages: 1 - on a mesh shaked substrate, 2 - on a paper absorptive material. The fat content was measured with Soxhlet method (Sobol et al., 2018). The results were analysed in STATISTICA 13.1 on the set significance level of $\alpha=0.05$. 
Zygmunt Sobol, Tomasz Jakubowski, Paulina Wrona

\section{Results and discussion}

The analysis of variance in the triple classification shows that stimulation of tubers $\{1\}$, type of frying fat $\{3\}$, have a statistically significant impact on the fat content in dry mass of French fries (Table 1). All interactions between the accepted factors were statistically significant.

Table 1.

Impact of tubers stimulation manner, conditions of immersion of intermediate products and a type of frying fat on the fat content in dry mass of French fries (analysis of variance in a triple classification)

\begin{tabular}{lccccc}
\hline Quality predictor & $\begin{array}{c}\text { Sum } \\
\text { of squares }\end{array}$ & $\begin{array}{c}\text { Degrees } \\
\text { of freedom }\end{array}$ & $\begin{array}{c}\text { Mean } \\
\text { square }\end{array}$ & $\begin{array}{c}\text { FSndecor } \\
\text { test }\end{array}$ & P test \\
\hline Free expression & 55737.37 & 1 & 55737.37 & 555.526 & 0.000 \\
\hline$\{1\}$ Stimulation manner & 745.96 & 2 & 372.98 & 3.717 & 0.039 \\
\hline$\{2\}$ Conditions of immersion & 174.76 & 3 & 58.25 & 0.581 & 0.633 \\
\hline$\{3\}$ type of frying pan & 1536.94 & 1 & 1536.94 & 15.318 & 0.001 \\
\hline $1 * 2$ & 1168.74 & 6 & 194.79 & 1.941 & 0.115 \\
\hline $1 * 3$ & 62.62 & 2 & 31.31 & 0.312 & 0.735 \\
\hline $2 * 3$ & 562.49 & 3 & 187.50 & 1.869 & 0.162 \\
\hline $1 * 2 * 3$ & 491.29 & 6 & 81.88 & 0.816 & 0.568 \\
\hline Error & 2407.98 & 24 & 100.33 & & \\
\hline
\end{tabular}

In the experiment that was carried out, a higher fat content was reported (Fig. 1) in a dry mass of French fries (average 36.65\%) from potato bulbs irradiated with UV-C referred to the control sample (28.92\%) (but French fries from tubers irradiated for 30 minutes on one side of a tuber had a higher fat content $(38.49 \%)$ in comparison to French fries from tubers irradiated after 15 minutes on two sides $(34.71 \%)$. Multiple comparison of average couples (Duncan test) proved a statistically significant difference in the fat content in French fries from the control sample and from tubers irradiated with UV-C for 30 minutes on one side. Existence of two homogeneous groups of variables were showed (Table 2). A sample that consisted of French fries from tubers irradiated after 15 minutes on two opposite sides was qualified to both uniform groups (the so-called overlapping of groups) which makes it impossible to clearly interpret the obtained result. The above system of the obtained results may show that longer irradiation of potato tubers influences the increase of fat absorption of the fried product (French fries).

According to Zagórska and Smuga-Kogut (2014), a very important property from the nutritive point of view is a fat content in the product that is ready for consumption. In case of an intermediate for French fries, it depends on the dry mass and a starch content in raw material (potato tubers). A higher content of these components means less fat in a ready product (Lipska and Leszczyński, 1989). Additionally, the content of fat absorbed by French fries influences: a type of the used oil, thickness of sticks, blanching parameters, temperature, and drying time (Lipska and Leszczyński,1989). 
Impact of UV-C stimulation...

As Zgórska and Smuga-Kogut (2014) indicate, as a result of thermal processing of an intermediate into fried products, starch gelatinization that forms a coat-forming material takes place, which as a result causes formation on the surface, of a layer which prevents from fat absorption of fat to its inside. Acc. to Adamczyk et al. (2013) gelatinization is a process that is related to starch seed expansion under the influence of water in a raised temperature. In this process, inter and intra -particle hydrogen bonding of starch components crack. Water washes out amylose from a seed which forms a colloid in combination with water. Disintegrating bondings are hydrogen bondings and a newly formed are bondings, also hydrogen ones, between a polymer and water (hydration). A possible cause of the increased fat absorption by French fries from a raw material irradiated with ultraviolet are damages of $\alpha$-glycoside bondings (combining glucose particles) resulting from the UV-C activity. Damages will cause weakening of the starch seeds expansion process which will translate into a germination ability and as a result into an increased fat absorption.

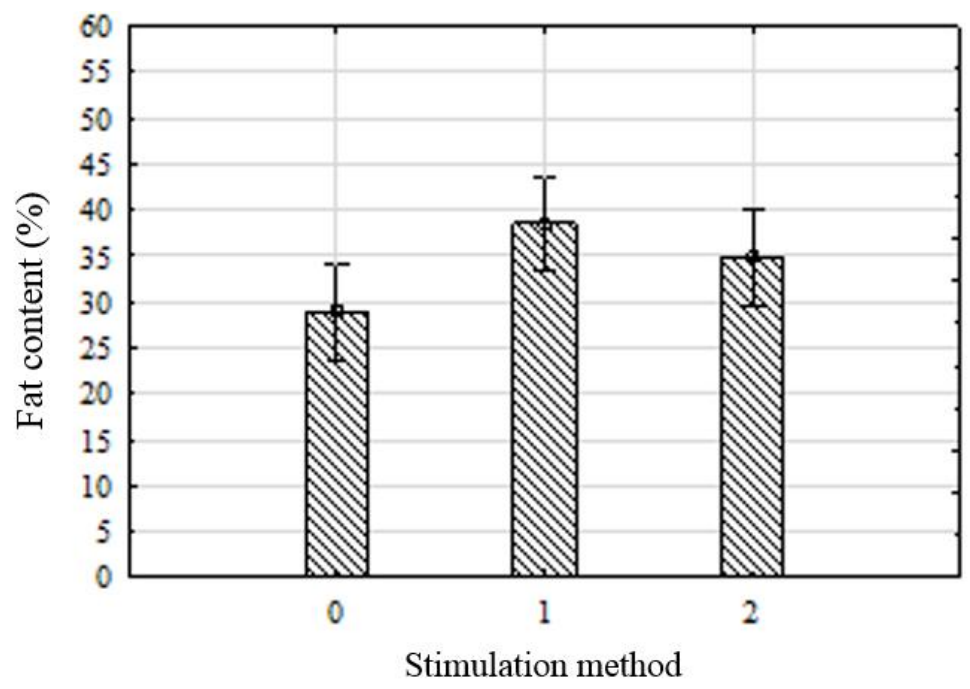

Figure 1. Impact of potato tubers stimulation method on the fat content in dry mass of French fries

Table 2.

Duncan test results - Uniform groups offat content in dry mass of French fries for the method of stimulation

\begin{tabular}{|c|c|c|c|}
\hline \multirow{3}{*}{ Stimulation method } & \multicolumn{3}{|c|}{$\begin{array}{l}\text { Fat content in dry mass of French fries } \\
\qquad(\%)\end{array}$} \\
\hline & \multirow{2}{*}{ Average } & \multicolumn{2}{|c|}{ Homogeneous groups } \\
\hline & & 1 & 2 \\
\hline 0 & 28,92 & $* * * *$ & \\
\hline 2 & 34,81 & $* * * *$ & $* * * *$ \\
\hline 1 & 38,49 & & $* * * *$ \\
\hline
\end{tabular}


The applied conditions of immersion of intermediates in water have no statistically significant impact on the fat content in dry mass of French fries (Table 1, Fig. 2). The fat content was from ca. $31 \%$ in samples where before frying intermediates were subjected to the blanching process to ca. $35 \%$ in the remaining conditions of immersion and in the zero sample. In fact, the applied conditions of immersion caused a change in the density of intermediate products to the maximum level of $|-0.009|\left(\mathrm{g}^{\circ} \mathrm{cm}^{-3}\right)$ (Sobol et al., 2018). This did not significantly affect the mass of the absorbed fat in the frying process. A small change in the density of intermediates as a result of immersion in a water bath (conditions from 1 to 3 ) resulted most probably from an insignificant change (increase) of the osmotic pressure in cells. A nonsignificant change of the osmotic pressure in cells caused by transpiration of tubers was related most probably to a short (several days) period between harvesting and processing.

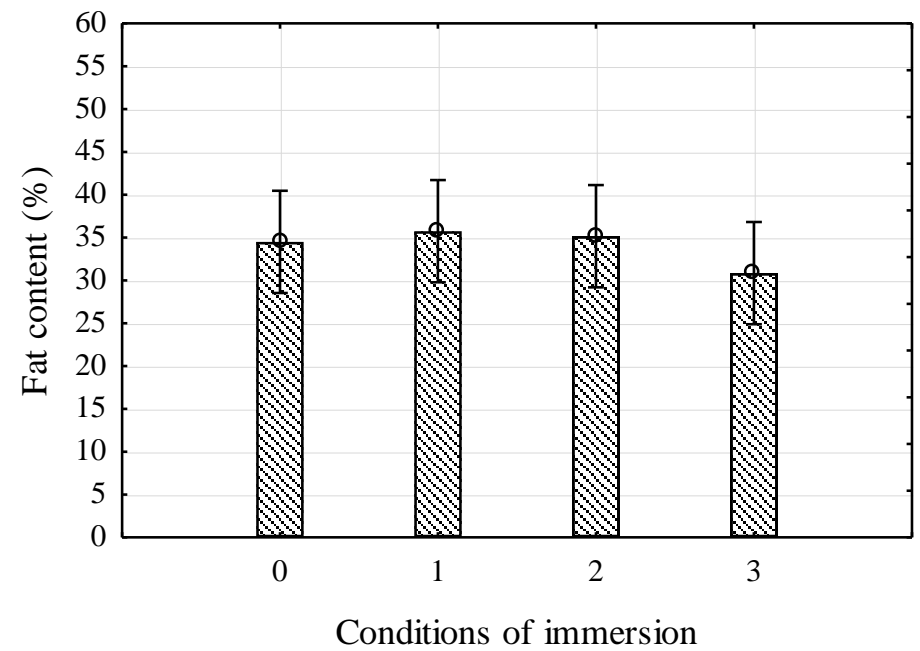

Figure 2. Impact of conditions of immersion of intermediates in water on fat content in dry mass of French fries

A content of fat, fat acids in French fries, crisps and other snacks is very varied and depends on the type of the applied frying medium (Balas, 2004; Kita, 2006; Kita et al., 2003). Balas (2004) and Kita et al., (2003) claim that the fat content in crisps is varied and within 26.3 to $39.0 \%$ and depends on the used frying oil. Kita (2006) concludes that products fried in rapeseed oil absorb less fat than those fried in palm oil and in the mixture of palm and rapeseed oil.

The experiment that was carried out shows that there is a statistically significant difference in the total fat content in dry mass of French fries depending on the applied frying medium (Table 1, Fig. 3). A higher content of fat in dry mass had French fries fried in the refined rapeseed oil (ca. 40\%) and less those fried in coconut oil (ca. 28\%) (Fig. 3). 
Impact of UV-C stimulation...

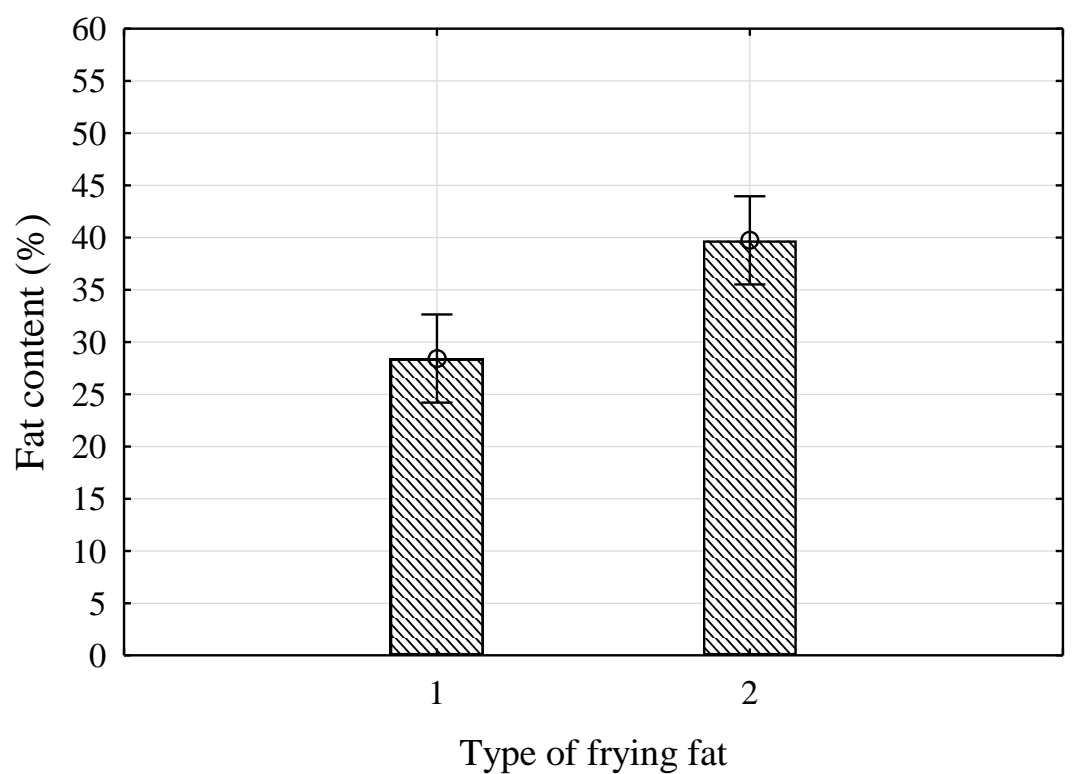

Figure 3. Impact of frying fat type on fat content in dry mass of French fries

\section{Conclusions}

1. The fat content in dry mass of French fries statistically significantly depends on the UV$\mathrm{C}$ stimulation of tubers and the type of the used frying fat.

2. The UV-C stimulation of tubers increases the fat content in dry mass of French fries $(36.65 \%)$ in comparison to the zero sample (without stimulation) $(28.92 \%)$.

3 . The use of refined rapeseed oil for frying causes the increase of the fat content in dry mass of French fries (ca. 40\%) in comparison to coconut oil (ca. 28\%).

\section{References}

Adamczyk, G., Krystyjan, M., Dobosz, A., Sikora, M. (2013). Tiksotropowe właściwości skrobi, ŻYWNOŚĆ. Nauka. Technologia. Jakość, 6(91), 16-31.

Aguilera, J.M., Gloria-Hernandez, H. (2000). Oil Absorption During Frying of Frozen Parfried Potatoes. Journal of Food Science, 65, 3.

Balas, J. (2004). Kwasy tłuszczowe w rynkowych produktach spożywczych - oleje, margaryny, masło, tłuszcze mieszane, produkty cukiernicze, produkty typu ,Fast food”, produkty zbożowe, słone przekąski, nasiona i orzechy. Żywienie Człowieka i Metabolizm, 2, 181-192.

Billek, G. (2000). Health aspects of thermoxidized oils and fats. European Journal of Lipid Science and Technology, 102, 587-593.

Bouchon, P., Aguilera, J.M. (2001). Microstructural analysis of frying potatoes. International Journal of Food Science and Technology, 36, 669-676. 
Bouchon, P., Hollins, P., Pearson, M., Pyle, D.L., Tobin, M.J. (2001). Oil Distribution in Fried Potatoes Monitored by Infrared Microspectroscopy. Journal of Food Science, 7(66). 918-923.

Dana, D., Saguy, I.S. (2006). Review. Mechanism of oil uptake during deep-fat frying and the surfactant effect-theory and myth. Advances in Colloid and Interface Science, 128-130, 267-272.

Dobarganes, C., Márquez-Ruiz, G., Velasco, J. (2000). Interactions between fat and food during deepfrying. European Journal of Lipid Science and Technology, 102, 521-528.

Friedman, B. (2000). Adsorbent antioxidant provides optimum frying in restaurant and fast food fryers. European Journal of Lipid Science and Technology, 102, 560-565.

Jakubowski, T. (2015). Transfer of microwave irradiation effects of seed potatoes (Solanum tuberosum L.) to the plants of next generations. Bulgarian Journal of Agricultural Science, 6, 1185-1193.

Jakubowski, T. (2016). Effect of microwave radiation on the germination of Solanum Tuberosum L. tubers. Bangladesh Journal of Botany, 5, 1253-1255.

Jakubowski, T., Pytlowski, T. (2013). Influence of ultraviolet radiation on the growth, development and yielding of potato plants (preliminary studies). Agricultural Engineering, 3, 99-107.

Jakubowski, T., Wrona, P. (2012). Wpływ promieniowania mikrofalowego na ciemnienie miąższu bulw Ziemniaka. Technica Agraria Acta Scientarum Polonorum, 11(3-4), 55-633.

Jakubowski, T., Pytlowski, T. (2015). Influence of UV-C radiation on the degree of infection of stored potato tubers by Rhizoctonia Solani Kühn. Agricultural Engineering, 154(2), 35-43.

Kita, A, Aniołkowski, K., Włodarczyk, E. (2003). Zmiany frakcji tłuszczowej w przechowywanych produktach przekąskowych. Zeszyty Naukowe Akademii Rolniczej we Wrocławiu, 35(2), 88-89.

Kita, A. (2006). Wpływ wybranych parametrów technologicznych na jakość smażonych produktów przekąskowych. Zeszyty Naukowe Akademii Rolniczej we Wrocławiu, 537, Rozprawy 240.

Krokida, M.K., Oreopoulou, V., Maroulis, Z.B. (2000). Effect of frying conditions on shrinkage and porosity of fried potatoes. Journal of Food Engineering, 43, 147-154.

Krokida, M.K., Oreopoulou, V., Maroulis, Z.B. (2000). Water loss and oil uptake as a function of frying time. Journalof Food Engineering, 44, 39-46.

Lisińska, G. (1994). Ziemniak jako surowiec dla przemysłu. Wymagania w stosunku do surowca Postęy Nauk Rolniczych, 1, 32-40.

Lisińska, G. (2006). Wartość technologiczna i jakość konsumpcyjna polskich odmian ziemniaka Zeszyty Problemowe Postępów Nauk Rolniczych, 511, 81-94.

Lisińska, G., Leszczyński, W. (1989). Potato Science and Technology. Elservier Applied Science. London, New York

Marks, N. (2005). Influence of changing magnetic field on storage losses of potato tubers. Agricultural Engineering, 70(10), 295-302.

Mellema, M. (2003). Mechanism and reduction of fat uptake in deep-fat fried foods. Trends in Food Science \& Technology, 14, 364-373.

Moyano, P.C., Pedreschi, F. (2006). Kinetics of oil uptake during frying of potato slices: Effect of pretreatments. LWT-Food Science and Technology, 39, 285-291.

Pedreschi, F., Cocio, C., Moyano, P., Troncoso, E. (2008). Oil distribution in potato slices during frying. Journal of Food Engineering, 87, 200-212.

Pedreschi, F., Moyano, P. (2005). Oil uptake and texture development in fried potato slices. Journal of Food Engineering, 70, 557-563.

Rimac-Brncic, S., Lelas, V., Rade, D., Simundic, B. (2004). Decreasing of oil absorption in potato strips during deep fat frying. Journal of Food Engineering, 64, 237-241.

Saguy, I. S., Dana, D. (2003). Integrated approach to deep fat frying: engineering, nutrition, health and consumer aspects. Journal of Food Engineering, 56, 143-152.

Sobol, Z., Jakubowski, T., Wrona, P. (2018). The effect of UV-C stimulation of potato tubers and soaking of potato strips in water on density differences of intermediates for French-fry production. BIO Web of Conferences, 10, 02031.

Sobol, Z. (2006a). Zmiana ubytku gęstości bulw ziemniaka w wyniku absorpcji wody. Acta Agrophysica, 8(4), 985-993. 
Impact of UV-C stimulation...

Sobol. Z. 2006b. Wpływ wybranych czynników na gęstość bulw ziemniaka. Acta Agrophysica, 8(1), 219-228.

Sobol, Z. (2007). Zmiany ubytków gęstości słupków i plastrów wyciętych z bulw ziemniaka wynikające z absorpcji wody. Acta Agrophysica, 10(1), 219-228.

Sobol, Z. (2016). Effect of water immersion of semi-finished products on the fat content in fried potato products. Agricultural Engineering, 20(4), 183-194

Zgórska, K., Smuga-Kogut, K. (2014). Jak ograniczyć zawartość tłuszczu we frytkach ziemniaczanych. Ziemniak Polski, 1, 38-42

\title{
WPLYW STYMULACJI UV-C BULW, ZANURZENIA SLUPKÓW ZIEMNIACZANYCH W WODZIE ORAZ RODZAJU FRYTURY NA ZAWARTOŚĆ TŁUSZCZU W SUCHEJ MASIE FRYTEK
}

\begin{abstract}
Streszczenie. Celem przeprowadzonego eksperymentu było określenie wpływu stymulacji UV-C bulw, zanurzenia słupków ziemniaczanych w wodzie oraz rodzaju frytury na zawartość tłuszczu w suchej masie frytek. Badania przeprowadzono na bulwach odmiany Innovator, która jest jedną $\mathrm{z}$ najchętniej stosowanych $\mathrm{w}$ produkcji frytek przez firmy europejskie jak również polskie. Naświetlanie bulw ziemniaka ultrafioletem w paśmie $\mathrm{C}$ wykonano z zastosowaniem autorskiego stanowiska do stymulacji materiału biologicznego promieniowaniem elektromagnetycznym. Analiza statystyczna otrzymanych wyników badań wskazuje, że stymulacja bulw i rodzaj frytury, miały statystycznie istotny wpływ na zawartość tłuszczu w suchej masie frytek.
\end{abstract}

Słowa kluczowe: stymulacja UV-C, bulwy ziemniaka, półprodukty, tłuszcz, zanurzenie w wodzie 